\title{
Effect of Covid-19 on Food Consumption Pattern of Indian Adolescent Girls
}

\section{Jyoti Singh $^{1 *}$ and Nikita Wadhawan ${ }^{2}$}

${ }^{1}$ Research Scholar, Department of Food Science and Nutrition, MPUAT, Udaipur,

Rajasthan, India

${ }^{2}$ Assistant Professor, Department of Renewable Energy Engineering, MPUAT,

Udaipur, Rajasthan, India

*Corresponding Author: Jyoti Singh, Research Scholar, Department of Food Science and Nutrition, MPUAT, Udaipur, Rajasthan, India.
Received: July 12, 2021

Published: September 24, 2021

(C) All rights are reserved by Jyoti Singh and

Nikita Wadhawan.

\begin{abstract}
Since the beginning of 2020, coronavirus disease (COVID-19) has become a major public health issue. Adolescences constitute about 21 percent of Indian population. It is an important phase of human life and the habits form during this period can last longer. This sudden outbreak of pandemic can have an impact on their dietary patterns. Therefore, current study was undertaken to assess the effect of COVID-19 on food consumption pattern of adolescent girls. For carrying out the investigation, 120 urban adolescent girls aged 13-18 years were purposively selected from two schools of Udaipur district, Rajasthan. A well-structured interview schedule consisted of food frequency list was prepared and pretested. Data on food consumption pattern before and during COVID-19 was collected from selected samples through personal interview in month of march 2021, keeping in mind COVID-19 guidelines. SPSS version 26 was used for analysing all the data. The findings of the study revealed that COVID-19 had affected consumption pattern of food such as ginger, garlic, fruits such as banana, kinoo, apple, grapes, non-vegetarian food such as mutton, chicken, fish, beverages such as lemon water, turmeric milk, herbal tea, carbonated beverages and junk foods. COVID-19 had marginally improved the consumption pattern of immunity booster's food among adolescent girls.
\end{abstract}

Keywords: Covid-19; Food Consumption Pattern; Food Groups; Adolescent Girls; Immunity

\section{Introduction}

A pneumonia illness first emerged in Wuhan, China, in late December 2019, and has since expanded globally, resulting in the coronavirus pandemic, also known as COVID-19 disease which was caused by the coronavirus-2 [1]. India recorded its first case of COVID-19 on January, 2020 [2]. The virus spread quickly and widely in a short period of time, causing fear and forcing public health officials to impose restrictions in many nations throughout the world, including travel bans, social gathering restrictions, and school closures [3]. As a consequence, India's government imposed a 21-day national lockdown on March 24, 2020, prohibiting the movement of the country's 1.3 billion citizens. The union government also imposed a nationwide lockdown of schools and institutions on March 16, 2020. Furthermore, government advisories such as AYUSH have recommended ways to keep the public safe during pandemics. The Ministry of Health has provided guide- lines for practitioners on how to deal with the pandemic, including immunity-boosting foods, warm water drinking, a well-balanced diet, and physical activity, among other things [4].

Children establish health-related lifestyle patterns, which are reinforced during adolescence. They have a significant impact on health later in life, making the early stages of life crucial for the acquisition and maintenance of healthy habits [5]. Youngsters are more open to novelty and change, which can be a beneficial trait in certain contexts, but they are also more vulnerable to abrupt changes. Isolation during the epidemic has had an impact on diet, particularly among teenagers, who are particularly prone to developing unhealthy eating habits.

The complete confinement of the population in their homes due to lockdown imposed by government of India resulted in disruptions in daily activities of every individual [6]. A broad COVID-19 
outbreak induced significant mental health outcomes, including tension, anxiety, and depression among the affected people [7]. It is generally established that chronic stress effects overall health and may also change the health behaviours of the individuals, including their eating habits [8].

Cartwright., et al. (2003) [9] found that stress has an impact on adolescents' eating habits, as they reported lower consumption of fruits and vegetables and higher consumption of snacks and other fatty foods. These findings imply that the COVID-19 pandemic is linked to long-term stress, which could lead to dietary alterations [10]. The results of the study on Polish population by Sidor and Rzymski (2020) [11] confirmed that lockdowns may be a major dietary risk factor, since certain persons may exhibit poor eating habits, such as a low intake of fruits and vegetables and a high intake of sweets. Hourani, A. H., et al. [12] 2021 in their study concluded that when compared to before the lockdown, consumption of all food groups increased dramatically. In a study on Italian adolescent study, it was found that lower age groups consumed more junk food, such as packaged sweets, baked goods, sweet beverages, and savoury snacks during COVID-19 confinement [13]. On the other hand, other investigators observed that during the pandemic, teenagers in Spain, Italy, Brazil, Chile, and Colombia increased their consumption of vegetables, fruit, and legumes by a significant amount [14].

Till now most of the studies have been done globally for assessing the effect of COVID-19 on food consumption pattern. However, all these studies have been done immediately after COVID-19 lockdown or during lockdown but none of recent studies have been done to assess changes after lockdown and also no Indian data is available on effect of COVID-19 on adolescent's food consumption pattern. Hence, taking into account the conflicting findings of previous studies on teenage food patterns, the current study set out to investigate the effect of COVID-19 on food consumption pattern among urban adolescent girls.

\section{Methodology}

- Sample selection: The present study was conducted in Udaipur city, Rajasthan in month of March 2021 while following COVID-19 guidelines. One hundred and twenty samples aged 13-18 years of girls were purposively selected from two schools of Udaipur district, Rajasthan. Sixty girls were taken from each school who were willing to participate and were not suffering from any known disease.
- Development of tool: Research tool was developed keeping in mind the objectives of the study. Questionnaire was prepared and pretested for collecting data from selected samples and interview technique was used for gathering information from all the subjects. Questionnaire consisted of two sections where first section analysed the socio-demographic information of the respondents which included data such as age, religion, caste, family type and size, education and occupation of parents, annual income of the family and second section was prepared to assess food consumption pattern of subjects pre and during COVID-19. Food frequency checklist analysed the consumption of food groups such as cereals, pulses, fruits, other vegetables, green leafy vegetables, root and tubers, milk and its products, eggs, meat and fish, fats and oils, beverages and junk foods on daily, weekly, fortnightly, monthly, rarely, not consumed basis.

- Data analysis: Descriptive statistics (Frequency and percentage) identified the socio demographic and food consumption pattern responses to the questionnaire. The data of before and during COVID-19 was compared using student paired t-test with the help of SPSS 26 version. A significance level of $p<$ 0.01 and $p<0.05$ was applied to the analysis.

\section{Results and Discussion}

Sociodemographic information of the respondents

Table 1 shows half of respondents belonged to age group 1315 years and another half belonged to age group 16-18 years. Majority of respondents were Hindu (88.33\%), belonged to general category (65\%), had nuclear (78.33\%) and medium size $(69.16 \%)$ families. Majority of respondent fathers were graduate $(46.67 \%)$ and had private job (57.50\%) whereas most of subject's mother were intermediate passed (35\%) and were housewives. (84.17\%). Annual income of most (80\%) of the families ranged between 2.5 to 5 lakhs and majority $(72.50 \%)$ were vegetarian.

\begin{tabular}{|c|c|c|c|}
\hline S. No. & Variables & Frequency & Percentage \\
\hline 1. & Age (years) & & \\
\hline & $13-15$ & 60 & 50 \\
\hline & $16-18$ & 60 & 50 \\
\hline 2 & Religion & & \\
\hline & Hindu & 106 & 88.33 \\
\hline & Muslim & 5 & 4.17 \\
\hline & Christian & 0 & 0 \\
\hline & Sikh & 2 & 1.67 \\
\hline
\end{tabular}




\begin{tabular}{|c|c|c|c|}
\hline & Buddhist/Neo-Buddhist & 0 & 0 \\
\hline & Jain & 7 & 5.83 \\
\hline \multirow[t]{5}{*}{3} & Caste & & \\
\hline & General & 78 & 65 \\
\hline & OBC & 24 & 20 \\
\hline & $\mathrm{SC}$ & 13 & 10.83 \\
\hline & ST & 5 & 4.17 \\
\hline \multirow[t]{3}{*}{4.} & Type of Family & & \\
\hline & Nuclear & 94 & 78.33 \\
\hline & Joint & 26 & 21.66 \\
\hline \multirow[t]{4}{*}{5.} & Family size & & \\
\hline & Small & 26 & 21.66 \\
\hline & Medium & 83 & 69.16 \\
\hline & Large & 11 & 9.16 \\
\hline \multirow[t]{8}{*}{6.} & Father Education & & \\
\hline & Illiterate & 0 & 0 \\
\hline & Primary & 4 & 3.33 \\
\hline & Middle & 5 & 4.16 \\
\hline & High school & 8 & 6.67 \\
\hline & Intermediate & 38 & 31.67 \\
\hline & Graduation & 56 & 46.67 \\
\hline & Post-graduation & 9 & 7.50 \\
\hline \multirow[t]{8}{*}{7.} & Mother Education & & \\
\hline & Illiterate & 5 & 4.16 \\
\hline & Primary & 8 & 6.67 \\
\hline & Middle & 18 & 15 \\
\hline & High school & 36 & 30 \\
\hline & Intermediate & 42 & 35 \\
\hline & Graduation & 11 & 9.17 \\
\hline & Post-graduation & 0 & 0 \\
\hline \multirow[t]{5}{*}{8.} & Father Occupation & & \\
\hline & Farmer & 13 & 10.83 \\
\hline & Business & 26 & 21.67 \\
\hline & Private Job & 69 & 57.50 \\
\hline & Government Job & 12 & 10 \\
\hline \multirow[t]{5}{*}{9.} & Mother Occupation & & \\
\hline & Housewife & 97 & 80.83 \\
\hline & Business & 12 & 10 \\
\hline & Private Job & 8 & 6.67 \\
\hline & Government Job & 3 & 2.50 \\
\hline \multirow[t]{5}{*}{10.} & Annual income of family & & \\
\hline & Up to 2.5 Lakhs & 96 & 80 \\
\hline & 2.5-5 Lakhs & 22 & 18.33 \\
\hline & 5-10 Lakhs & 2 & 1.67 \\
\hline & $>10$ lakhs & 0 & 0 \\
\hline \multirow[t]{4}{*}{11.} & Food habits & & \\
\hline & Vegetarian & 87 & 72.50 \\
\hline & Non vegetarian & 16 & 13.33 \\
\hline & Ova vegetarian & 17 & 14.17 \\
\hline
\end{tabular}

Table 1: Socio-demographic information of respondents and their families $(n=120)$.
Changes in food consumption pattern during COVID-19

- Change in Cereals: Table 2 clearly depicted that the consumption pattern of cereals such as wheat, rice, maize, oats remained same during COVID-19.

- Change in Pulses: No changes in eating pattern of pulses such as green gram, black gram, red lentils, rajmah, chickpea, brown chickpea, red gram was noted.

- Changes in root and tubers: The consumption pattern of root and tuber such as Potato, Onion and Colocasia root remained same as before the pandemic except for garlic and ginger. Garlic was consumed by $10 \%$ on daily basis, $34.16 \%$ consumed it on weekly basis before COVID-19 and the mean score was $3.40 \pm 1.71$ whereas $14.16 \%$ consumed it daily and $33.33 \%$ had it on weekly basis during COVID-19 and the mean score was $3.22 \pm 1.74$. Table 3 indicate that there was significant difference $(0.18 \pm 0.48, \mathrm{p}<0.05)$ in consumption pattern of garlic during COVID-19. Majority (35.83\%) of girls consumed ginger on weekly basis before COVID-19 and the mean score was $(3.52 \pm 1.78)$ whereas during COVID-19 the mean score changed to $(3.24$ 1.78). It is clear from table 3 that there was significant difference in consumption pattern of ginger $(0.480 .85, \mathrm{p}<0.05)$. These changes can be attributed to the fact that ministry of ayush has recommended to increase the consumption of ginger and garlic during this pandemic as these foods will be helpful in fighting against corona virus (Indian Express, 2021) ${ }^{(15)}$. The most preferred immune enhancers among all participants were ginger and garlic. This was concluded in a study by Basu., et al. 2020 [16].

- Changes in green leafy vegetables: It was noted that there was no change in consumption pattern of green leafy vegetables.

- Changes in Other vegetables: Table 2 and table 3 clearly demonstrated that there was no change in consumption pattern of other vegetables.

- Changes in fruits: No change in eating habit of fruits such as papaya, sapota, guava, pomegranate, pineapple and strawberry were noted during the pandemic except for banana, kinoo, apple and grapes. Banana was consumed by majority (27.5\%) on weekly basis before COVID-19 and the mean score was 3.79 1.53. Whereas during COVID-19 the percentage of girls consuming banana on weekly basis changed to $29.16 \%$ and the mean score becomes 3.65 1.49. Table 3 demonstrated that 
there was significant difference $(0.140 .41, \mathrm{p}<0.05)$ in consumption of banana during COVID-19. Apple was consumed by girls on weekly basis was $14.16 \%$ before during COVID-19 and the mean score was 4.00 1.19. During Covid-19, the percentage of girls consuming apple on weekly basis becomes $20.83 \%$ and the mean score was 3.76 1.24. It is clear from the table 3 that there was significant difference in consumption pattern (0.24 $0.57, \mathrm{p}<0.05)$ of apple. Kinoo consumed by girls on fortnightly basis before COVD-19 was $22.5 \%$ and the mean score was 3.69 1.17. The percentage of girl who consumed kinoo on fortnightly becomes $33.33 \%$ during COVID-19 and the mean score was 3.32 1.14. Table depicted that there was significant difference $(0.360 .62, p<0.05)$ in eating pattern of kinoo during COVID-19. The percentage of girls who consumed grapes on fortnightly basis before COVID-19 was $12.5 \%$ and the mean score was 3.74 1.25. During COVID-19, the percentage of girls consuming grapes on fortnightly basis was $19.16 \%$ and the mean score becomes 3.67 1.2. So, this change indicates that there was significant difference $(0.060 .25, \mathrm{p}<0.01)$ in consumption pattern of grapes. These changes in eating pattern of fruits among adolescents contributed due to the reason that the parents of subjects were might aware of the fact that having fruits in their diet will help fight against corona virus and builds immune system. Similar results were reported in study done by Ruiz-Roso, M.B., et al. 2020 [14] among teenagers residing in Spain, Italy, Brazil, Chile, and Colombia, where before COVID-19 confinement only $25.5 \%$ of teenagers consumed one fruit per day whereas $33.2 \%$ consumed one fruit per day during confinement.

- Changes in Non-vegetarian foods: Change in the eating pattern of mutton, fish, chicken was seen during COVID-19 but no change in consumption of eggs was noted. Mutton was never consumed by majority (96.66\%) of girls before COVID-19 and the mean score was 5.930 .36 whereas during COVID-19, $100 \%$ of girls never had mutton in their diet. This change indicates that there was significant difference $(-0.060 .36, \mathrm{p}<$ 0.01 ) in eating pattern of mutton. Regarding the consumption of fish, it was found that $91.66 \%$ of girls never had fish in their diet before COVID-19, but this percentage changed to $98.33 \%$ during COVID-19. Table 3 clearly demonstrated that there was change $(-0.130 .50, \mathrm{p}<0.05)$ in eating pattern of fish during COVID-19. Whereas chicken was consumed by $13.33 \%$ on monthly basis before COVID-19 but only $5.83 \%$ of them had it during COVID-19. Significant difference $(-0.100 .40, \mathrm{p}<0.05)$ in eating pattern of chicken seen during COVID-19. It was concluded in a study by Rahman, C.K., et al. (2021) [15] that during COVID-19 pandemic and the lockdown period, nonvegetarians' meat eating patterns were determined to have changed. During the lockdown, the majority of consumers were unable to purchase appropriate quantities of meat and meat products due to a variety of factors including increased costs and decreased livestock availability. The development of SARS-CoV-2 and the myths and rumours linked with meat intake drastically reduced the meat trade in some areas.

- Changes in beverages: No significant changes in the consumption pattern of beverages such as tea and coffee were seen whereas there was significant difference in the consumption pattern of lemon water, turmeric milk, herbal tea and carbonated beverages. Lemon water was taken by $29.16 \%$ of girls on fortnightly basis before COVID-19 and the mean score was 4.05 1.15. During COVID-19, 36.66\% started having it on fortnightly basis. This change suggested that there was significant difference $(0.21 \pm 0.62, \mathrm{p}<0.01)$ in consumption pattern of lemon water. Table 2 depicted that $80 \%$ of adolescent girls never had turmeric girl during COVID-19 and this percentage changed to $65 \%$ during the pandemic time. This is clear from the given data in table 3 that there was significant difference (0.4 0.88, $\mathrm{p}<0.01)$ in consumption pattern of turmeric milk. Kaur., et al. $2020^{(4)}$ in their study noted that before the pandemic $85.5 \%$ of all respondents do not consume lemon water whereas during COVID-19 there was reduction in the percentage $(20 \%)$ of subjects who never consumed lemon on daily basis. Also, change in habit of taking turmeric milk was noted by them where only $2.7 \%$ of subjects were turmeric milk before COVID-19 and during COVID-19, 305 of respondents started consuming turmeric milk. Herbal tea was never consumed by $80 \%$ of girls before the pandemic and this percentage changed to $84.16 \%$ during COVID-19. This suggested that there was significant change $(0.30 \quad 0.83, \mathrm{p}<0.01)$ in consumption pattern of having herbal tea. The percentage of girls having carbonated beverages before the pandemic on monthly basis was $25 \%$ whereas during COVID-19 only $15.83 \%$ were consuming it on monthly basis. It was clear from table 3 that there was significant difference in consumption pattern of carbon- 
ated beverages. Di Renzo., et al. 2020 [13] discovered in their study among adolescents that $16.7 \%$ of the population altered their habits by consuming less carbonated and sugary beverages, sweets, and savory foods. Alamrawy, R.G., et al. 2021 [16] concluded in their study that during the pandemic, $29.3 \%$ of subjects reported reduction in intake of carbonated beverages among Egyptian populations aged 14-24 years.

- Changes in Junk foods: Consumption of fast food stimulates the intrinsic immune system while suppressing adaptive immunity, resulting in persistent inflammation and weakened viral defences [17]. Majority (41.66\%) of girls were having junk foods on weekly basis before COVID-19 and the mean score was $2.18 \pm 0.97$. During the pandemic, weekly consumption of junk food during COVID-19 changed to $36.66 \%$ of girls and the mean score was 2.401 .01 . Table 3 clearly indicate that there was significant change $(-0.21 \pm 0.45, \mathrm{p}<0.01)$ in the eating pattern of junk foods among adolescent girls. In a study among children's and adolescents aged 8-18 years of Egypt it was found that during pandemic $77.1 \%$ of subjects reported reduced consumption of junk food outside their home [18]. A study conducted by Singh, B., et al. 2021 [19] among Indian adults' population it was concluded that $73.8 \%$ of subjects reduced their intake of junk food during COVID-19 pandemic.

\begin{tabular}{|c|c|c|c|c|c|c|c|}
\hline Food stuff & Sample & $\begin{array}{l}\text { Daily } \\
(\%)\end{array}$ & $\begin{array}{l}\text { Weekly } \\
(\%)\end{array}$ & $\begin{array}{c}\text { Fortnightly } \\
\text { (\%) }\end{array}$ & $\begin{array}{l}\text { Monthly } \\
\text { (\%) }\end{array}$ & $\begin{array}{c}\text { Rarely } \\
(\%)\end{array}$ & $\begin{array}{l}\text { Never } \\
(\%)\end{array}$ \\
\hline \multicolumn{8}{|c|}{ Cereals } \\
\hline \multirow[t]{2}{*}{ Wheat } & Before COVID & 100 & 0 & 0 & 0 & 0 & 0 \\
\hline & During COVID & 100 & 0 & 0 & 0 & 0 & 0 \\
\hline \multirow[t]{2}{*}{ Rice } & Before COVID & 48.3 & 37.5 & 4.17 & 2.5 & 1.67 & 5.83 \\
\hline & During COVID & 48.3 & 37.5 & 4.17 & 2.5 & 1.67 & 5.83 \\
\hline \multirow[t]{2}{*}{ Maize } & Before COVID & 0 & 12.5 & 35.8 & 21.7 & 15.8 & 14.2 \\
\hline & During COVID & 0 & 12.5 & 35.8 & 21.7 & 15.8 & 14.2 \\
\hline \multirow[t]{2}{*}{ Oats } & Before COVID & 0 & 11.7 & 13.3 & 23.3 & 19.2 & 14.2 \\
\hline & During COVID & 0 & 11.7 & 13.3 & 23.3 & 19.2 & 14.2 \\
\hline \multicolumn{8}{|c|}{ Pulses and Legumes } \\
\hline \multirow[t]{2}{*}{ Green gram (Moong) } & Before COVID & 0 & 20 & 33.33 & 26.7 & 8.33 & 11.7 \\
\hline & During COVID & 0 & 20 & 33.33 & 26.7 & 8.33 & 11.7 \\
\hline \multirow[t]{2}{*}{ Black gram (Urad) } & Before COVID & 0 & 18.3 & 27.5 & 22.5 & 16.7 & 15 \\
\hline & During COVID & 0 & 18.3 & 27.5 & 22.5 & 16.7 & 15 \\
\hline \multirow[t]{2}{*}{ Red lentils (masoor) } & Before COVID & 0 & 35.83 & 30 & 16.66 & 9.16 & 8.33 \\
\hline & During COVID & 0 & 35.83 & 30 & 16.66 & 9.16 & 8.33 \\
\hline \multirow[t]{2}{*}{ Rajmah } & Before COVID & 0 & 6.66 & 23.33 & 35.83 & 26.66 & 7.5 \\
\hline & During COVID & 0 & 6.66 & 23.33 & 35.83 & 26.66 & 7.5 \\
\hline \multirow[t]{2}{*}{ Chickpea (Chole) } & Before COVID & 0 & 7.5 & 9.16 & 59.16 & 17.5 & 6.66 \\
\hline & During COVID & 0 & 7.5 & 9.16 & 59.16 & 17.5 & 6.66 \\
\hline \multirow{2}{*}{$\begin{array}{l}\text { Brown chickpea (kala } \\
\text { chana) }\end{array}$} & Before COVID & 0 & 0 & 20 & 60.83 & 9.16 & 10 \\
\hline & During COVID & 0 & 0 & 20 & 60.83 & 9.16 & 10 \\
\hline \multirow[t]{2}{*}{ Red gram (arhar dal) } & Before COVID & 0 & 51.66 & 17.5 & 11.66 & 5 & 14.16 \\
\hline & During COVID & 0 & 51.66 & 17.5 & 11.66 & 5 & 14.16 \\
\hline \multicolumn{8}{|c|}{ Root and Tubers } \\
\hline \multirow[t]{2}{*}{ Potato } & Before COVID & 100 & 0 & 0 & 0 & 0 & 0 \\
\hline & During COVID & 100 & 0 & 0 & 0 & 0 & 0 \\
\hline
\end{tabular}




\begin{tabular}{|c|c|c|c|c|c|c|c|}
\hline \multirow[t]{2}{*}{ Onion } & Before COVID & 94.16 & 0 & 0 & 0 & 0 & 5.83 \\
\hline & During COVID & 94.16 & 0 & 0 & 0 & 0 & 5.83 \\
\hline \multirow[t]{2}{*}{ Colocasia root (arbi) } & Before COVID & 0 & 0 & 15 & 25 & 38.33 & 21.66 \\
\hline & During COVID & 0 & 0 & 15 & 25 & 38.33 & 21.66 \\
\hline \multirow[t]{2}{*}{ Garlic } & Before COVID & 10 & 34.16 & 10 & 16.66 & 9.166 & 20 \\
\hline & During COVID & 14.16 & 33.33 & 14.16 & 12.5 & 5.83 & 20 \\
\hline \multirow[t]{2}{*}{ Ginger } & Before COVID & 10 & 35.83 & 7.5 & 4.16 & 24.16 & 18.33 \\
\hline & During COVID & 12.5 & 38.33 & 9.166 & 7.5 & 17.5 & 15 \\
\hline \multicolumn{8}{|c|}{ Green leafy Vegetables } \\
\hline \multirow[t]{2}{*}{ Spinach } & Before COVID & 0 & 35 & 11.66 & 20.83 & 15 & 17.5 \\
\hline & During COVID & 0 & 35 & 11.66 & 20.83 & 15 & 17.5 \\
\hline \multirow[t]{2}{*}{ Fenugreek Leaves } & Before COVID & 0 & 0 & 17.5 & 35.83 & 24.16 & 22.5 \\
\hline & During COVID & 0 & 0 & 17.5 & 35.83 & 24.16 & 22.5 \\
\hline \multirow[t]{2}{*}{ Bathua } & Before COVID & 0 & 19.16 & 13.33 & 16.66 & 27.5 & 23.33 \\
\hline & During COVID & 0 & 19.16 & 13.33 & 16.66 & 27.5 & 23.33 \\
\hline \multirow[t]{2}{*}{ Amaranth leaves (cholai) } & Before COVID & 0 & 6.66 & 10.83 & 9.16 & 15.833 & 57.5 \\
\hline & During COVID & 0 & 6.66 & 10.83 & 9.16 & 15.833 & 57.5 \\
\hline \multirow[t]{2}{*}{ Spring onion } & Before COVID & 0 & 15 & 33.33 & 25.83 & 11.66 & 14.16 \\
\hline & During COVID & 0 & 15 & 33.33 & 25.83 & 11.66 & 14.16 \\
\hline \multicolumn{8}{|c|}{ Other vegetabl } \\
\hline \multirow[t]{2}{*}{ Brinjal } & Before COVID & 0 & 14.16 & 30 & 20.83 & 15.83 & 19.16 \\
\hline & During COVID & 0 & 14.16 & 30 & 20.83 & 15.83 & 19.16 \\
\hline \multirow[t]{2}{*}{ Lady finger } & Before COVID & 0 & 35.83 & 26.66 & 17.5 & 8.33 & 11.66 \\
\hline & During COVID & 0 & 35.83 & 26.66 & 17.5 & 8.33 & 11.66 \\
\hline \multirow[t]{2}{*}{ Bottle gourd (Lauki) } & Before COVID & 0 & 10 & 20.83 & 30.83 & 12.5 & 25.833 \\
\hline & During COVID & 0 & 10 & 20.83 & 30.83 & 12.5 & 25.833 \\
\hline \multirow[t]{2}{*}{ Cauliflower } & Before COVID & 0 & 30.83 & 25.83 & 22.5 & 16.66 & 4.16 \\
\hline & During COVID & 0 & 30.83 & 25.83 & 22.5 & 16.66 & 4.16 \\
\hline \multirow[t]{2}{*}{ Capsicum } & Before COVID & 0 & 42.5 & 25.83 & 16.66 & 5 & 10 \\
\hline & During COVID & 0 & 42.5 & 25.83 & 16.66 & 5 & 10 \\
\hline \multirow[t]{2}{*}{ Bitter Gourd (Kerala) } & Before COVID & 0 & 0 & 7.5 & 28.33 & 18.33 & 45.83 \\
\hline & During COVID & 0 & 0 & 7.5 & 28.33 & 18.33 & 45.83 \\
\hline \multirow[t]{2}{*}{ Pumpkin } & Before COVID & 0 & 7.5 & 30 & 25 & 15 & 22.5 \\
\hline & During COVID & 0 & 7.5 & 30 & 25 & 15 & 22.5 \\
\hline \multirow[t]{2}{*}{ Ivy gourd (Kundru) } & Before COVID & 0 & 6.66 & 31.66 & 27.5 & 15.83 & 18.33 \\
\hline & During COVID & 0 & 6.66 & 31.66 & 27.5 & 15.83 & 18.33 \\
\hline \multirow[t]{2}{*}{ Ridge Gourd (Turai) } & Before COVID & 0 & 9.16 & 28.33 & 16.66 & 13.33 & 32.5 \\
\hline & During COVID & 0 & 9.16 & 28.33 & 16.66 & 13.33 & 32.5 \\
\hline \multirow[t]{2}{*}{ Cabbage } & Before COVID & 0 & 39.16 & 21.66 & 18.33 & 5.83 & 15 \\
\hline & During COVID & 0 & 39.16 & 21.66 & 18.33 & 5.83 & 15 \\
\hline
\end{tabular}




\begin{tabular}{|c|c|c|c|c|c|c|c|}
\hline \multicolumn{8}{|c|}{ Fruits } \\
\hline \multirow[t]{2}{*}{ Banana } & Before COVID & 0 & 27.5 & 23.33 & 15.83 & 9.166 & 24.16 \\
\hline & During COVID & 0 & 29.16 & 25.83 & 16.66 & 7.5 & 20.83 \\
\hline \multirow[t]{2}{*}{ Papaya } & Before COVID & 0 & 0 & 8.33 & 20 & 22.5 & 49.16 \\
\hline & During COVID & 0 & 0 & 8.33 & 20 & 22.5 & 49.16 \\
\hline \multirow[t]{2}{*}{ Sapota (Chikoo) } & Before COVID & 0 & 15 & 23.33 & 12.5 & 21.66 & 27.5 \\
\hline & During COVID & 0 & 15 & 23.33 & 12.5 & 21.66 & 27.5 \\
\hline \multirow[t]{2}{*}{ Apple } & Before COVID & 0 & 14.16 & 17.5 & 32.5 & 25 & 10.83 \\
\hline & During COVID & 0 & 20.83 & 20 & 29.16 & 21.66 & 8.33 \\
\hline \multirow[t]{2}{*}{ Kinoo } & Before COVID & 0 & 20 & 22.5 & 31.66 & 20 & 5.83 \\
\hline & During COVID & 0 & 27.5 & 33.33 & 24.16 & 9.16 & 5.833 \\
\hline \multirow[t]{2}{*}{ Grapes } & Before COVID & 0 & 25 & 12.5 & 32.5 & 23.33 & 6.66 \\
\hline & During COVID & 0 & 25 & 19.16 & 25.83 & 23.33 & 6.66 \\
\hline \multirow[t]{2}{*}{ Guava } & Before COVID & 0 & 10 & 14.16 & 26.66 & 35 & 14.16 \\
\hline & During COVID & 0 & 10 & 14.16 & 26.66 & 35 & 14.16 \\
\hline \multirow[t]{2}{*}{ Pomegranate } & Before COVID & 0 & 10.83 & 19.16 & 20 & 15.83 & 34.16 \\
\hline & During COVID & 0 & 10.83 & 19.16 & 20 & 15.83 & 34.16 \\
\hline \multirow[t]{2}{*}{ Pineapple } & Before COVID & 0 & 0 & 0 & 15 & 37.5 & 47.5 \\
\hline & During COVID & 0 & 0 & 0 & 15 & 37.5 & 47.5 \\
\hline \multirow[t]{2}{*}{ Strawberry } & Before COVID & 0 & 0 & 11.66 & 15.83 & 21.66 & 50.83 \\
\hline & During COVID & 0 & 0 & 11.66 & 15.83 & 21.66 & 50.83 \\
\hline \multicolumn{8}{|c|}{ Milk and Milk products } \\
\hline \multirow[t]{2}{*}{ Milk } & Before COVID & 25 & 29.16 & 0 & 0 & 0 & 45.83 \\
\hline & During COVID & 25 & 29.16 & 0 & 0 & 0 & 45.83 \\
\hline \multirow[t]{2}{*}{ Curd } & Before COVID & 8.33 & 50 & 14.16 & 0 & 0 & 27.5 \\
\hline & During COVID & 8.33 & 50 & 14.16 & 0 & 0 & 27.5 \\
\hline \multirow[t]{2}{*}{ Paneer } & Before COVID & 0 & 0 & 12.5 & 20 & 26.66 & 40.83 \\
\hline & During COVID & 0 & 0 & 12.5 & 20 & 26.66 & 40.83 \\
\hline \multirow[t]{2}{*}{ Buttermilk } & Before COVID & 7.5 & 20.83 & 17.5 & 13.33 & 11.66 & 29.16 \\
\hline & During COVID & 7.5 & 20.83 & 17.5 & 13.33 & 11.66 & 29.16 \\
\hline \multicolumn{8}{|c|}{ Egg, meat, Fish } \\
\hline \multirow[t]{2}{*}{ Mutton } & Before COVID & 0 & 0 & 0 & 33.33 & 0 & 96.66 \\
\hline & During COVID & 0 & 0 & 0 & 0 & 0 & 100 \\
\hline \multirow[t]{2}{*}{ Fish } & Before COVID & 0 & 0 & 0 & 8.33 & 0 & 91.66 \\
\hline & During COVID & 0 & 0 & 0 & 1.66 & 0 & 98.33 \\
\hline \multirow[t]{2}{*}{ Chicken } & Before COVID & 0 & 0 & 0 & 13.33 & 0 & 86.66 \\
\hline & During COVID & 0 & 0 & 0 & 5.83 & 4.166 & 90 \\
\hline
\end{tabular}




\begin{tabular}{|c|c|c|c|c|c|c|c|}
\hline \multirow[t]{2}{*}{ Eggs } & Before COVID & 0 & 5 & 6.66 & 15 & 0 & 73.33 \\
\hline & During COVID & 0 & 5 & 6.66 & 15 & 0 & 73.33 \\
\hline \multicolumn{8}{|c|}{ Fats and oil } \\
\hline \multirow[t]{2}{*}{ Desi Ghee } & Before COVID & 37.5 & 21.66 & 0 & 0 & 25 & 15.83 \\
\hline & During COVID & 37.5 & 21.66 & 0 & 0 & 25 & 15.83 \\
\hline \multirow[t]{2}{*}{ Butter } & Before COVID & 0 & 31.66 & 19.16 & 15 & 10.83 & 23.33 \\
\hline & During COVID & 0 & 31.66 & 19.16 & 15 & 10.83 & 23.33 \\
\hline \multirow[t]{2}{*}{ Refined Oil } & Before COVID & 20.83 & 35 & 14.16 & 6.66 & 13.33 & 10 \\
\hline & During COVID & 20.83 & 35 & 14.16 & 6.66 & 13.33 & 10 \\
\hline \multirow[t]{2}{*}{ Mustard Oil } & Before COVID & 62.5 & 28.33 & 0 & 0 & 0 & 9.16 \\
\hline & During COVID & 62.5 & 28.33 & 0 & 0 & 0 & 9.16 \\
\hline \multicolumn{8}{|c|}{ Beverages } \\
\hline \multirow[t]{2}{*}{ Tea } & Before COVID & 37.5 & 20 & 0 & 0 & 28.33 & 14.16 \\
\hline & During COVID & 37.5 & 20 & 0 & 0 & 28.33 & 14.16 \\
\hline \multirow[t]{2}{*}{ Coffee } & Before COVID & 5 & 20.83 & 10.83 & 15.83 & 14.16 & 33.33 \\
\hline & During COVID & 5 & 20.83 & 10.83 & 15.83 & 14.16 & 33.33 \\
\hline \multirow[t]{2}{*}{ Lemon Water } & Before COVID & 0 & 7.5 & 29.16 & 25 & 26.66 & 11.66 \\
\hline & During COVID & 0 & 9.16 & 36.66 & 26.66 & 15.83 & 11.66 \\
\hline \multirow[t]{2}{*}{ Turmeric Milk } & Before COVID & 0 & 1.66 & 5 & 4.16 & 9.166 & 80 \\
\hline & During COVID & 0 & 6.66 & 8.33 & 7.5 & 12.5 & 65 \\
\hline \multirow[t]{2}{*}{ Herbal Tea } & Before COVID & 0 & 0 & 1.66 & 3.33 & 0 & 95 \\
\hline & During COVID & 0 & 0 & 10 & 5.83 & 0 & 84.16 \\
\hline \multirow[t]{2}{*}{ Carbonated beverages } & Before COVID & 0 & 15 & 38.33 & 25 & 9.16 & 12.5 \\
\hline & During COVID & 0 & 11.66 & 41.66 & 15.83 & 15 & 15.83 \\
\hline \multirow[t]{2}{*}{ Junk Food } & Before COVID & 26.66 & 41.66 & 18.33 & 13.33 & 0 & 0 \\
\hline & During COVID & 20.83 & 36.66 & 24.16 & 18.33 & 0 & 0 \\
\hline
\end{tabular}

Table 2: Food Frequency before and during COVID-19 among adolescent girls $(\mathrm{n}=120)$.

\begin{tabular}{|c|c|c|c|c|}
\hline Food stuff & $\begin{array}{c}\text { Before COVID-19 Score } \\
\text { Mean } \pm \text { SD }\end{array}$ & $\begin{array}{c}\text { During COVID-19 Score } \\
\text { Mean } \pm \text { SD }\end{array}$ & $\begin{array}{c}\Delta \text { Change (Dur-Bef) }^{\$} \\
\text { Mean } \pm \text { SD }\end{array}$ & t value \\
\hline \multicolumn{5}{|l|}{ Cereals } \\
\hline Wheat & $1.00 \quad 0.00$ & $1.00 \quad 0.00$ & NA & NA \\
\hline Rice & 1.893 .008 & 1.893 .008 & NA & NA \\
\hline Maize & 3.831 .25 & 3.831 .25 & NA & NA \\
\hline Oats & 4.471 .37 & 4.471 .37 & NA & NA \\
\hline \multicolumn{5}{|l|}{ Pulses and Legumes } \\
\hline Green Gram (Moong) & 3.581 .23 & 3.581 .23 & NA & NA \\
\hline Black gram (Urad) & 3.831 .32 & 3.831 .32 & NA & NA \\
\hline Red lentils(masoor) & 3.241 .26 & 3.241 .26 & NA & NA \\
\hline Rajmah & 4.051 .03 & 4.051 .03 & NA & NA \\
\hline
\end{tabular}




\begin{tabular}{|c|c|c|c|c|}
\hline Chickpea (Chole) & 4.070 .91 & 4.070 .91 & NA & NA \\
\hline Brown chickpea (kala chana) & 4.090 .83 & 4.090 .83 & NA & NA \\
\hline Red gram (arhar dal) & 3.131 .45 & 3.131 .45 & NA & NA \\
\hline \multicolumn{5}{|l|}{ Root and tubers } \\
\hline Potato & 1.000 .00 & 1.000 .00 & NA & NA \\
\hline Onion & 1.291 .17 & 1.291 .17 & NA & NA \\
\hline Colocasia root (arbi) & 4.670 .98 & 4.670 .98 & NA & NA \\
\hline Garlic & 3.401 .71 & 3.221 .74 & 0.180 .48 & $4.14^{* *}$ \\
\hline Ginger & 3.521 .78 & 3.241 .78 & 0.480 .85 & $3.50^{* *}$ \\
\hline \multicolumn{5}{|l|}{ Green leafy Vegetables } \\
\hline Spinach & 3.681 .51 & 3.681 .51 & NA & NA \\
\hline Fenugreek Leaves & 4.521 .02 & 4.521 .02 & NA & NA \\
\hline Bathua & 4.221 .44 & 4.221 .44 & NA & NA \\
\hline Amaranth leaves (cholai) & 5.071 .30 & 5.071 .30 & NA & NA \\
\hline Spring onion & 3.771 .25 & 3.771 .25 & NA & NA \\
\hline \multicolumn{5}{|l|}{ Other vegetables } \\
\hline Brinjal & 3.961 .34 & 3.961 .34 & NA & NA \\
\hline Lady finger & 3.331 .34 & 3.331 .34 & NA & NA \\
\hline Bottle gourd (Lauki) & 4.231 .31 & 4.231 .31 & NA & NA \\
\hline Cauliflower & 3.381 .20 & 3.381 .20 & NA & NA \\
\hline Capsicum & 3.141 .29 & 3.141 .29 & NA & NA \\
\hline Bitter Gourd (Kerala) & 5.031 .02 & 5.031 .02 & NA & NA \\
\hline Pumpkin & 4.151 .28 & 4.151 .28 & NA & NA \\
\hline Ivy gourd (Kundru) & 4.081 .21 & 4.081 .21 & NA & NA \\
\hline Ridge Gourd (Turai) & 4.321 .41 & 4.321 .41 & NA & NA \\
\hline Cabbage & 3.361 .43 & 3.361 .43 & NA & NA \\
\hline \multicolumn{5}{|l|}{ Fruits } \\
\hline Banana & 3.791 .53 & 3.651 .49 & 0.140 .41 & $3.73^{* *}$ \\
\hline Papaya & 5.131 .00 & 5.131 .00 & NA & NA \\
\hline Sapota (Chikoo) & 4.231 .45 & 4.231 .45 & NA & NA \\
\hline Apple & 4.001 .19 & 3.761 .24 & $0.24 \quad 0.57$ & $4.56^{* *}$ \\
\hline Kinno & 3.691 .17 & 3.321 .14 & 0.360 .62 & $6.46^{* *}$ \\
\hline Grapes & 3.741 .25 & 3.671 .26 & 0.060 .25 & $2.91^{* *}$ \\
\hline Guava & 4.291 .17 & 4.291 .17 & NA & NA \\
\hline Pomegranate & 4.431 .40 & 4.431 .40 & NA & NA \\
\hline Pineapple & 5.330 .72 & 5.330 .72 & NA & NA \\
\hline Strawberry & 5.121 .06 & 5.121 .06 & NA & NA \\
\hline \multicolumn{5}{|l|}{ Milk and Milk products } \\
\hline Milk & 3.582 .26 & 3.582 .26 & NA & NA \\
\hline Curd & 3.11 .81 & 3.11 .81 & NA & NA \\
\hline Paneer & 4.961 .05 & 4.961 .05 & NA & NA \\
\hline Buttermilk & 3.881 .72 & 3.881 .72 & NA & NA \\
\hline \multicolumn{5}{|l|}{ Egg, meat, Fish } \\
\hline Mutton & 5.930 .36 & 6 & -0.060 .36 & $-2.02^{*}$ \\
\hline Fish & 5.830 .55 & 5.960 .25 & -0.130 .50 & $2.91^{* *}$ \\
\hline Chicken & 5.730 .68 & 5.840 .50 & -0.100 .40 & $2.92^{* *}$ \\
\hline Eggs & 5.301 .23 & 5.301 .23 & NA & NA \\
\hline \multicolumn{5}{|l|}{ Fats and oil } \\
\hline Desi Ghee & 3.012 .04 & 3.012 .04 & NA & NA \\
\hline Butter & 3.751 .56 & 3.751 .56 & NA & NA \\
\hline Refined Oil & 2.871 .63 & 2.871 .63 & NA & NA \\
\hline Mustard Oil & 1.741 .42 & $1.74 \quad 1.42$ & NA & NA \\
\hline
\end{tabular}




\begin{tabular}{|c|c|c|c|c|}
\hline Beverages & & & & \\
\hline Tea & 3.042 .03 & 3.042 .03 & NA & NA \\
\hline Coffee & 4.131 .69 & 4.131 .69 & NA & NA \\
\hline Lemon Water & 4.051 .15 & 3.841 .16 & 0.210 .62 & $3.80^{* *}$ \\
\hline Turmeric Milk & 5.600 .91 & 5.200 .11 & 0.40 .88 & $4.96^{* *}$ \\
\hline Herbal Tea & 5.880 .52 & 5.580 .98 & 0.300 .83 & $3.93^{* *}$ \\
\hline Carbonated beverages & 3.651 .21 & 3.811 .28 & $-0.15 \quad 0.44$ & $-3.86^{* *}$ \\
\hline Junk Food & 2.180 .97 & 2.401 .01 & -0.210 .45 & $-5.24^{* *}$ \\
\hline
\end{tabular}

Table 3: Comparison of mean scores of food consumption pattern before and during COVID-19 $(n=120)$.

\$: Difference of score from during COVID-19 and before COVID-19 for each item.

*Significant at $(\mathrm{p}<0.05)$

**Significant at $(\mathrm{p}<0.01)$

$\mathrm{NA}=$ The correlation and $\mathrm{t}$ cannot be computed because the standard error of the difference is 0 .

\section{Conclusion}

As per the results of the study it can be concluded that there was marginally improvement in consumption of immunity boosting food items such as garlic, ginger, fruits, beverages such as turmeric milk, lemon water, herbal tea during COVID-19 whereas the consumption of other food groups remained same as before the pandemic. There was reduction in habit of consuming junk foods and meat products among adolescents during COVID-19. It is important during this pandemic to promote healthy eating among adolescents and adding immune enhancing food stuffs to promote growth and development of adolescents' body.

\section{Bibliography}

1. Hui DS., et al. "The continuing 2019-nCoV epidemic threat of novel coronaviruses to global health-The latest 2019 novel coronavirus outbreak in Wuhan, China". International Journal of Infectious Diseases 91 (2020): 264-266.

2. Perappadan B S. "India's first coronavirus infection confirmed in Kerala". The Hindu (2020).

3. Rabi FA., et al. "SARS-CoV-2 and Coronavirus Disease 2019: What We Know So Far”. Pathogens 9.3 (2020). 231.

4. Kaur B., et al. "Impact of COVID-19 lockdown on the Dietary Pattern and Physical Activity of People". Journal of Humanities and Social Sciences Research 2 (2020): 205-216.
5. Miedema MD., et al. "Association of Fruit and Vegetable Consumption During Early Adulthood with the Prevalence of Coronary Artery Calcium After 20 Years of Follow-Up: The Coronary Artery Risk Development in Young Adults (CARDIA) Study". Circulation 132.21 (2015): 1990-1998.

6. W.H.O Coronavirus Disease (COVID-19) Pandemic (2020).

7. Rajkumar R P., et al. "COVID-19 and mental health: A review of the existing literature". Asian Journal of Psychiatry 52 (2020): 102066.

8. Hill DC., et al. "Stress and eating behaviors in children and adolescents: Systematic review and meta-analysis". Appetite 123. (2018) 14-22.

9. Cartwright M., et al. "Stress and dietary practices in adolescents". Health Psychology 22. (2003): 362.

10. Abbas AM., et al. "Dietary habits in adults during quarantine in the context of COVID-19 pandemic". Obesity Medicine 19 (2020): 100254.

11. Sidor A., et al. "Dietary Choices and Habits during COVID-19 Lockdown: Experience from Poland”. Nutrients 12.6 (2020): 1657.

12. Hourani AH., et al. "Impact of COVID-19 Lockdown on Body Weight, Eating Habits, and Physical Activity of Jordanian Children and Adolescents". Disaster Medicine and Public Health Preparedness (2021): 1-9. 
13. Di Renzo L., et al. "Eating habits and lifestyle changes during COVID-19 lockdown: An Italian survey". Journal of Translational Medicine 18.229 (2020): 1-15.

14. Ruiz-Roso., et al. "Covid-19 Confinement and Changes of Adolescent's Dietary Trends in Italy, Spain, Chile, Colombia and Brazil". Nutrients 17 (2020): 1807.

15. COVID-19: Ayush Ministry recommends preventive Ayurveda measures (2021).

16. Basu S., et al. "Impact of lockdown due to COVID-19 outbreak: lifestyle changes and public health concerns in India". International Journal of Indian Psychology 82 (2020): 1385-1411.

17. Rahman CK., et al. "Impact of COVID-19 pandemic and lockdown on the meat consumption pattern in India: A preliminary analysis". Journal of Experimental Biology and Agricultural Sciences 9.2. (2021): 172-182.

18. Alamrawy RG., et al. "Psychiatric morbidity and dietary habits during COVID-19 pandemic: a cross-sectional study among Egyptian Youth (14-24 years)". Middle East Current Psychiatry 28. 6 (2021): 2-10.

19. Bohlouli J., et al. "COVID-19 and Fast Foods Consumption: A Review". International Journal of Food Properties 24.1 (2021): 203-209.

20. Khalil A M S., et al. "Children Dietary Habits and Quality of Sleep during COVID-19 Pandemic". International Journal of Nursing 7.2 (2020): 81-86.

21. Singh B., et al. "Effects of nationwide COVID-19 lockdown on lifestyle and diet: An Indian survey". Journal of Family Medicine and Primary Care 10. (2021): 1246-1250.

\section{Volume 4 Issue 10 October 2021}

(C) All rights are reserved by Jyoti Singh and Nikita Wadhawan. 